\title{
EFFECT OF WORK ASSESSMENT, WORK DISCIPLINE AND ORGANIZATIONAL COMMITMENT TO EMPLOYEE CAREER DEVELOPMENTPUBLIC WORKS AND SPATIAL ARRANGEMENTS REGENCY OF KARIMUN
}

\author{
Andykhatria ${ }^{1}$, Indrayani ${ }^{2}$, Mohamad Almansa Fitra ${ }^{3}$, Syahril ${ }^{4}$, \\ Hasudungan Hutasoit ${ }^{5}$, I Wayan Catra Yasa ${ }^{6}$ \\ Faculty of Economics, Department of Management, University of Batam \\ E-mail: ${ }^{1)}$ andykhatria12@gmail.com
}

\begin{abstract}
Competency-based HR management is a must, as a paradigm of the approach that is Career development is the process of improving skills, positions, and responsibilities. This study aims to determine the influence of performance assessment, work discipline and organizational commitment to employee career development. The population of this study is Civil Servants in the Public Works and Spatial Planning Office of Karimun Regency which amounts to 66 employees with a sample of 65 employees. The type of research used in this study is associative research. The method that can be used in this study is to use structural equation modeling (SEM) analysis based on variance, namely Partial Least Square (PLS). The research data was collected by questionnaire instrument. The results of the analysis in this study found that performance assessment had a positive and insignificant effect on employee career development $(\beta=0.270, p=$ 0.131 ) so it can be concluded that the results of the study rejected the first hypothesis. The results of the work discipline analysis showed a significant negative result with a probability value $(\beta=-$ $0.300, p=0.026$ ) so it can be concluded that the results of the study support the second hypothesis. The results of the organizational commitment analysis showed a significant positive result with a probability value $(\beta=0.293, p=0.039)$ so that it can be concluded that the results of the study support the third hypothesis. The study also showed that $21 \%$ of employee career development variables were influenced by performance assessment variables, work disciplines and organizational commitments while another $79 \%$ were influenced by other variables.
\end{abstract}

Keywords: performance assessment, work discipline, organizational commitment, career development

\section{INTRODUCTION}

Every human resource that works in a company or organization definitely wants an improvement in his career. A thriving career is often associated with the future of employees, although it does not guarantee a success. Career development is a process in a person's life that will be able to make the person more mature, better able to utilize his potential so as to achieve a career that suits him (Dessler, 2009). Everyone certainly wants a development or an improvement in their career. Although some people consider the development of one's career is influenced by luck, but in career development still needs proper planning and utilization of good opportunities so that the career can develop according to the wishes.

There are several things that can affect a person's career development and it is a human resource management task. The task of human resource management in this regard is to strive for every employee to have performance in accordance with organizational standards. Okpara 
EFFECT OF WORK ASSESSMENT, WORK DISCIPLINE AND ORGANIZATIONAL COMMITMENT TO EMPLOYEE CAREER DEVELOPMENTPUBLIC WORKS AND SPATIAL ARRANGEMENTS REGENCY OF KARIMUN

DOI: https://doi.org/10.54443/ijerlas.v2i1.146

(2006) stated that employee performance assessment is one of the basis of the decision to conduct a promotion or career development. The process carried out by the company in evaluating the performance of workers is often referred to as work performance assessment (Mangkuprawira, 2007). Pesiwarissa (2008) stated that achievement will determine a person's position in relation to the work he will handle and work experience in similar jobs into consideration in the framework of labor placement.

According to Arifin, \&Barnawi (2012: 112), work discipline is the ability of one's work to be regular, diligent, continuous, and work in accordance with the rules that apply by not violating the rules that have been set. Discipline is a condition of employee or employee self-control and orderly behavior that indicates the true level of cooperation within an organization. One important aspect of an employee's or employee's internal relationship but often difficult to implement is indicates a high level of a person's tendency to survive as a member of an organization, strong identification with the organization as well as active involvement in the organization

\section{IMPLEMENTATION METHOD}

\section{Types of Research}

The type of research used in this study is associative research whose relationship is influence or not. In this study, associative methods were used to determine the influence of performance assessment, work discipline and organizational commitment to the career development of employees in the Public Works and Spatial Planning Office of Karimun Regency.

\section{Population and Samples}

The sample population is all Civil Servants (PNS) Public Works and Spatial Planning Karimun district which is as many as 66 employees. The number of samples to be used is as many as 65 people. The method used is the survey method which is data collection using questionnaires

\section{Partial Least Square (PLS) Model Scheme}

This research model will be analyzed using Partial Least Square (PLS) method with SmartPLS 3.0 software. PLS is one of the alternative methods of Structural Equation Modeling (SEM) that can be done to solve problems in the relationship between variables that are very complex but small data sample sizes (30-100 samples) and have non- parametric assumptions, meaning that the data does not refer to any particular distibusi (Yamin and Kurniawan, 2009). 


\section{Outer Model Evaluation}

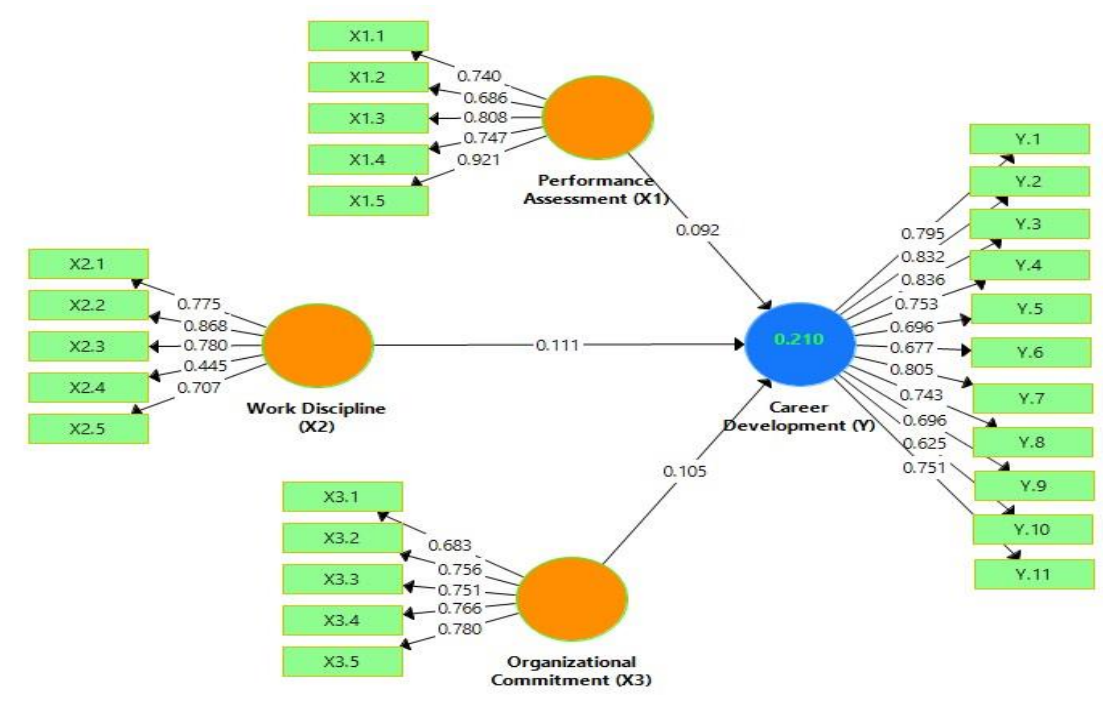

Figure 1. Outer Model Results

\section{Inner Model Evaluation}

After testing the outer model that has met,

the next test of the inner model (structural model). The inner model can be evaluated by looking at the r-square (indicator reliability) for dependent variables and the t-statistical value of coefficient testing. The higher the $r$ - square value means the better the predictive model of the proposed research model. The path value of coefficients indicates the degree of significance in hypothesis testing. In this study will be explained about the results of coefficient path test, goodness of fit test and hypothesis test.

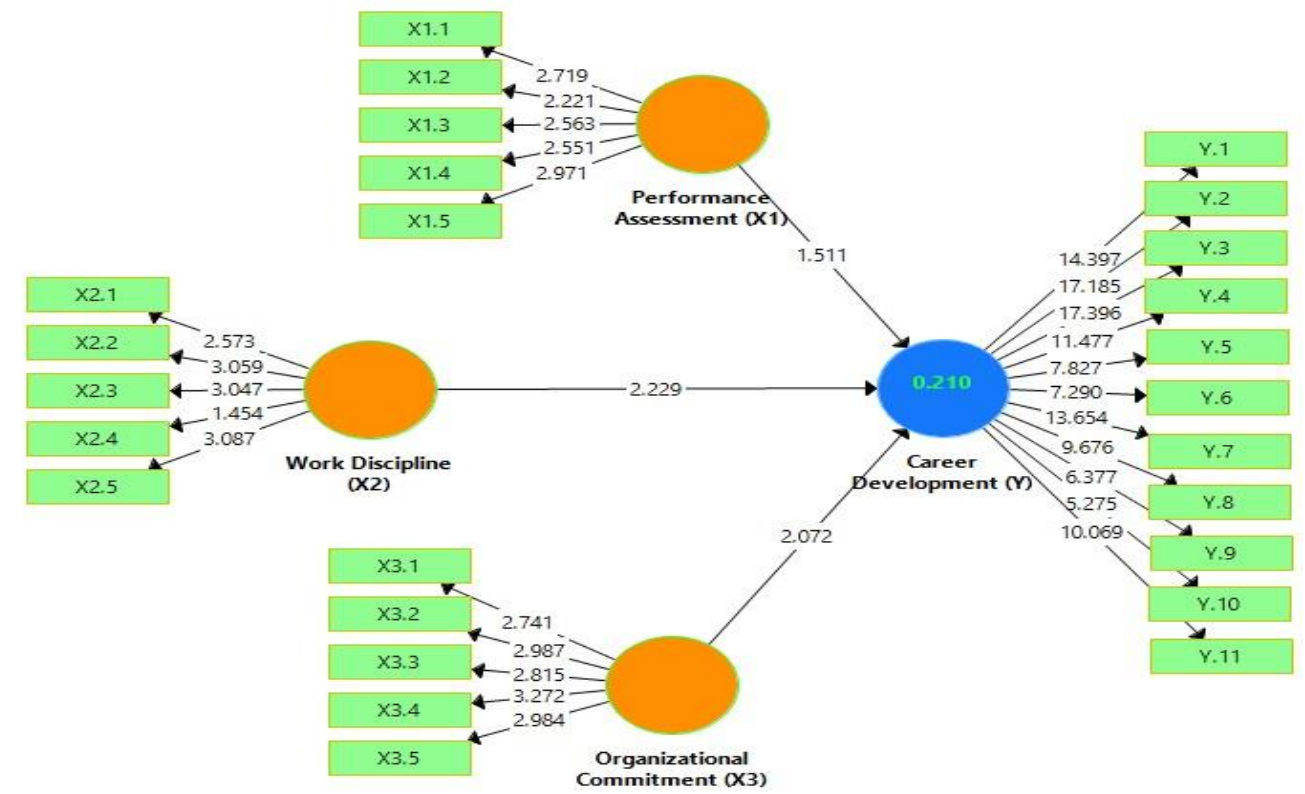

Figure 2. Inner Model Results (Bootsrapping) 
EFFECT OF WORK ASSESSMENT, WORK DISCIPLINE AND ORGANIZATIONAL COMMITMENT TO EMPLOYEE CAREER DEVELOPMENTPUBLIC WORKS AND SPATIAL ARRANGEMENTS REGENCY OF KARIMUN

DOI: https://doi.org/10.54443/ijerlas.v2i1.146

\section{RESULTS AND DISCUSSION}

1. Effect of Performance Assessment on Career Development of Public Works And Spatial Planning of Karimun Regency The results of the first hypothesis test showed that the test directly influenced the performance assessment on the career development of employees of of the Public Works And Spatial Planning Karimun Regency, obtained a Beta coefficient value of 0.270 , with a t-statistical value of 1.511 , and p-value of 0.131 . Because the $t$-statistical value of $<1.96$ (t table significant 5\%), and $p$-value $>0.05$, there is an insignificant direct influence between performance assessment and career development of employees of the Public Works And Spatial Planning Karimun Regency. Thus the first hypothesis cannot be proven.

2. Effect of Work Discipline on Career Development of Public Works And Spatial Planning of Karimun Regency The results of the second hypothesis test showed that the test of direct influence between work disciplines on the career development of employees of the Public Works And Spatial Planning Karimun Regency, obtained a Beta coefficient value of 0.300 with a statistical t value of 2.229 , and $p$ - value of 0.026 . Because the $t$-statistical value of $>1.96$ ( $t$ table significant 5\%), and $p$-value $<0.05$, there is a significant direct influence between work discipline and career development of employees of the Public Works And Spatial Planning Karimun Regency. Thus the second hypothesis can be proven.

3. Effect of Organizational Commitment on Career Development of Public Works And Spatial Planning of Karimun Regency The results of the analysis showed that the test of direct influence between organizational commitment to the career development of employees of the Public Works And Spatial Planning Office of Karimun Regency, obtained by beta coefficient value of 0.293 with a statistical $t$ value of 2.072 , and $p-$ value of 0.039 . Because the $\mathrm{t}$-statistical value $>1.96$ ( $\mathrm{t}$ table significant $5 \%$ ), and $\mathrm{p}$-value < 0.05 , there is a significant direct influence between organizational commitment and career development of employees of the Public Works Office and Spatial Planning Karimun Regency. Thus the third hypothesis can be proven

\section{DISCUSSION}

Based on the overall calculation result, the information can be obtained objectively as follows:

\section{Effect of Performance Assessment (X1) on Career Development (Y)}

The magnitude of the influence of performance assessment (X1) on employee career development $(\mathrm{Y})$ was 0.270 or $27.0 \%$, meaning an insignificant improvement in performance assessment increased career development by $27.0 \%$. This means that the better the performance assessment given, it does not affect the career development of employees in the Public Works and Spatial Planning Office of Karimun Regency. Kuswadi (2004:33) suggests that employees will perform well if they have high personal motivation, each motive characterized by a strong desire to achieve certain types of targets, such as career development. However, the results of this study are certainly different from various studies that have been done before. This is because performance assessment is not an important factor that can improve the career development of 
employees in the Public Works and Spatial Planning Office of Karimun Regency but there are other factors that become the benchmark to get promotion of positions in order to develop a career.

\section{Effect of Work Discipline (X2) on Career Development (Y)}

The magnitude of the influence of work discipline (X2) on career development (Y) is 0.300 or $30.0 \%$, meaning that improving employee discipline significantly increases career development opportunities. This means that the more disciplined the employee, the higher the opportunity to get the opportunity to develop a career in the Public Works and Spatial Planning Office of Karimun Regency. The results of this study are in line with research conducted by Asriati, Eviana (2017) which states that if a service office employee has good discipline in working, where the career of a service office employee becomes better development.

\section{Effect of Organizational Commitment (X3) on Career Development (Y)}

The magnitude of the influence of organizational commitment (X3) on career development (Y) by 0.293 or $29.3 \%$, meaning an increase in commitment to the organization / agency significantly increases the chances of career development of employees. This means that the greater the commitment of employees to the organization / agency, the more wide open opportunities to develop a career in the Public Works and Spatial Planning Office karimun. The results of this study are in line with those expressed by Armawati, Devia (2016) suggesting that career development has a significant impact on organizational commitments. Although the results of the study tested the opposite variable but the influence that is shared between the two variavel has significant results.

The joint influence of performance assessment (X1), work discipline (X2) and organizational commitment (X3) on career development (Y) was 0.210 or $21.0 \%$, while the remaining $79.0 \%$ was influenced by other factors not included in this study model. This means that every time there is a change in performance assessment, work discipline and organizational commitment it can affect career development up to $21.0 \%$.

\section{CONCLUSION}

From the results of the data analysis that has been done, it can be concluded as follows:

1. Partially, performance assessment has an insignificant influence on the career development of employees of the Public Works and Spatial Planning Office of Karimun Regency. Performance assessment has a positive influence which means career development is not very significantly influenced by good performance assessment, but also influenced by other factors. Based on this research, it can be concluded that hypothesis 1 that states performance assessment (X1) has a significant positive effect on the career development of employees (Y) of the Public Works and Spatial Planning Office of Karimun District is rejected.

2. Partially, the discipline of work has a significant influence on the career development of employees of the Public Works And Spatial Planning Office of Karimun Regency. Work discipline has a positive influence which means career development will increase if employees are more disciplined with the rules that have been made and agreed. Therefore, the agency is expected to provide promotional rewards for employees who have followed the rules and discipline in working. Based on this research, it can be concluded 
EFFECT OF WORK ASSESSMENT, WORK DISCIPLINE AND ORGANIZATIONAL COMMITMENT TO EMPLOYEE CAREER DEVELOPMENTPUBLIC WORKS AND SPATIAL ARRANGEMENTS REGENCY OF KARIMUN

DOI: https://doi.org/10.54443/ijerlas.v2i1.146

that hypothesis 2 that states the discipline of work (X2) has a significant positive effect on the career development of employees (Y) of the Public Works And Spatial Planning Office of Karimun Regency is accepted.

3. Partially, organizational commitment has a significant influence on the career development of employees of the Public Works and Spatial Planning Office of Karimun Regency. Organizational commitment has a positive influence which means career development will increase if employees have a high commitment to the organization / agency. Therefore, every employee should instill a loyal attitude to the organization / agency and increase the loyalty of work to the agency so that the agency does not hesitate to provide promotion of a better promotion of office to employees who are highly dedicated to orgnaisasi / agency. Based on this research, it can be concluded that hypothesis 3 that states that work discipline (X3) has a significant positive effect on the career development of employees (Y) of the Public Works And Spatial Planning Office of Karimun Regency is accepted.

4. There is a simultaneous influence between performance assessment variables, work disciplines and organizational commitments to the career development variables of public works and spatial planning of Karimun Regency as evidenced by the significance of $0.002<0.05$ and the coefficient result of 0.210 which means that employee career development can be explained by $21.0 \%$ by performance assessment variables, work disciplines and organizational commitments and the rest can be explained by other variables that are not contained in this study.

\section{REFERENCES}

Arikunto, S. 2010. Research Procedure: A Practical Approach. Jakarta: Rineka Cipta. Siagian, Sondang. P., 2007. Human Resources Management. Publisher of Bumi Aksara, Jakarta.

I.A Putu Kartika Dewi, I Gede Riana, 2015 Effect of Performance Assessment and Performance Experience on Career Development in PT. ORDINARY BALINESE BEAUTIFUL KUTABALI COLLECTION.

Burhannudin, Zainul, H. (2019). Effect of Work Discipline, Work Environment, and Organizational Commitment to Employee Performance: Study at Banjarmasin Islamic Hospital. Journal of Maksipreneur, Index Sinta 4, 8(2), 191-206.

Gde Bayu Surya Parwita, Made Ika Prastyadewi. Effect of Performance Assessment and Work Experience on Career Development. UNMAS Denpasar, Jl. Kamboja No.11a DenpasarBali Province 29-30 August 2016.

Okpara, John O. 2006. Gender and the relationship between perceived fairness in pay, promotion, and job satisfaction in a sub-Saharan African economy. Journal of Women in Management Review. pp: 224-240.

Christa Ruru, D., Kawet, L., and Taroreh, R., (2017), "The Influence of Discipline, Motivation, and Career Development on The Performance of Employees of the Revenue Office of Manado City, Manado.

Fauzi, Latifah Isnaini. (2018) Influence of Work Motivation and Work Experience on Employee Performance (Employee Case Study of PT Adi Satria Abadi), Yogyakarta. 
Ilham, R. N., Sadalia, I., Irawati, N., \& Sinta, I. (2022). Risk And Return Model of Digital Cryptocurrency Asset Investment In Indonesia. Al Qalam: Jurnal Ilmiah Keagamaan dan Kemasyarakatan, 16(1), 357-376.

Ilham, R. N., Sinaga, S., Putri, D. E., Sinta, I., \& Fuadi, F. (2021). EFEK DARI LEVERAGE DAN UKURAN PERUSAHAAN DALAM MEMENGARUHI TINGKAT PROFITABILITAS. JURNAL ILMIAH EDUNOMIKA, 5(02).

Khaddafi, M., \& Apriani, N. (2021). Analisis Kinerja Keuangan untuk Mengukur Tingkat Kesehatan Koperasi Simpan Pinjam Syariah di Kota Lhokseumawe. Jurnal EMT KITA, $5(1), 66-82$.

Mathis, L.R. and J.H. Jackson. (2006) Human Resource Management. Jakarta, Salemba Empat.

Rusydi, R., Adnan, A., Sutan, S., \& Bachri, N. (2021). THE INFLUENCE OF ENVIRONMENT, E-WOM, AND FACILITIES ON TOURIST DECISIONS TO VISIT SAWUEK RIVER, NORTH ACEH, INDONESIA. International Journal of Educational Review, Law And Social Sciences (IJERLAS), 1(2), 207-214.

Safitriani, Herman, H. (2020) "Influence of Discipline, Career Development and Motivation on Employee Performance of PT SatNusa Persada Tbk:, Management Journal, Vol. 13, No. 1,2020.

Simamora, Henry, (2004), Human Resource Management. Third Edition, STIE YKPN, Yogyakarta. 
EFFECT OF WORK ASSESSMENT, WORK DISCIPLINE AND ORGANIZATIONAL COMMITMENT TO EMPLOYEE CAREER DEVELOPMENTPUBLIC WORKS

AND SPATIAL ARRANGEMENTS REGENCY OF KARIMUN

DOI: https://doi.org/10.54443/ijerlas.v2i1.146 